\title{
Are Blood Transfusions Useful for Non-Specific Symptoms of Anemia in the Elderly?
}

\author{
Sakeena Raza ${ }^{1}$, Jeanne Wei ${ }^{1,2}$, Syed Ashad Abid ${ }^{1}$ and Gohar Azhar ${ }^{*}, 1,2$ \\ 'Reynolds Institute on Aging, University of Arkansas for Medical Sciences, Little Rock, Arkansas, USA \\ ${ }^{2}$ GRECC, Central Arkansas Veterans Health Care System, Little Rock, Arkansas, USA
}

\begin{abstract}
Background: Over $10 \%$ of adults older than 65 years have World Health Organization defined anemia (Hemoglobin lower than $13 \mathrm{~g} / \mathrm{dl}$ in men and $12 \mathrm{~g} / \mathrm{dl}$ in women). It is more prevalent with increasing age, exceeding $20 \%$ in the very elderly ( 85 years and older). Typical symptoms of anemia are nonspecific and often attributed to aging or to an exacerbation of another illness in the elderly.

Methods: We present a case series of patients between ages 65-99 years who were followed at the Senior Health clinic and presented with nonspecific symptoms. All these patients were found to have life-threatening anemia requiring blood transfusions.

Design: Case series.

Results: All our elderly patients experienced good outcomes in terms of resolution of their symptoms and improvement in functional status. There was a significant difference in the total number of symptoms pre-transfusion compared with symptoms post-transfusion $(\mathrm{p}<0.01)$. There were no adverse outcomes.

Conclusion: Our case series suggests that symptoms of anemia in the elderly are often attributed to aging or other disease co-morbidities. Nonspecific symptoms like dyspnea, fatigue and confusion should not be ignored. Management decisions regarding anemia should involve functional assessment of the elderly subject. Immediate arrangements for transfusion must be made if the elderly patient is symptomatic regardless of the hemoglobin level. If monitored appropriately, blood transfusions can prolong survival, improve quality of life and functional status of the older individual.
\end{abstract}

Keywords: Anemia, blood transfusions, elderly, non-specific symptoms.

\section{INTRODUCTION}

\section{Prevalence of Anemia in the Elderly}

Anemia affects approximately a third of the world's population and is a major factor in producing functional decline. In 2010, anemia was estimated to be responsible for 68.4 million years lived with disability (YLD) worldwide [1]. The World Health Organization (WHO) defines anemia as hemoglobin $(\mathrm{Hb})<13 \mathrm{~g} / \mathrm{dl}$ in men and $<12 \mathrm{~g} / \mathrm{dl}$ in women. According to this criterion, anemia in the elderly population is often under-recognized and as a result under-treated $[2,3]$. The Third National Health and Nutrition Examination Survey (NHANES III) reported the prevalence of WHO defined anemia among community dwelling adults of age 65years and older to be $11 \%$ and $10 \%$ in men and women respectively. The prevalence of anemia was also observed to increase with advancing age and among the oldest old (85 years and older), it was present in $29.3-30.7 \%$ of men and in $16.5-17.7 \%$ of women [4-6].

*Address correspondence to this author at the Reynolds Institute on Aging, University of Arkansas for Medical Sciences, 4301 West Markham, Slot 748, Little Rock, Arkansas, USA; Tel: (501) 526-5821; Fax: 501-686-6218; E-mail: AzharGohar@uams.edu

\section{Blood Transfusion Therapy for Anemia in the Elderly}

The American Association of Blood Banks (AABB) recommends restrictive transfusion strategy in stable hospitalized patients with transfusion only being considered for individuals with $\mathrm{Hb} \leq 7.0 \mathrm{~g} / \mathrm{dl}$. Certain exceptions have been made for patients with preexisting cardiovascular disease and for symptomatic postoperative surgical patients where transfusion threshold is higher at $\mathrm{Hb} \leq 8.0 \mathrm{~g} / \mathrm{dl}$. These recommendations are based only on a few randomized controlled trials that are not representative of many populations including patients with gastrointestinal bleeding, transfusion dependent patients as well as elderly patients recuperating from illnesses requiring hospitalizations [7].

Cumulative clinical experience as well as several studies conducted in the last 10 years suggest that in order to reduce debility, prolonged hospitalizations, medical complications, premature nursing home placement and death in the elderly anemic patients, interventions to correct the anemia may be required at a higher $\mathrm{Hb}$ level than that permitted under the restrictive transfusion strategy which has been adopted by most medical centers. There are a number of special considerations that apply in the early recognition of anemia 
in the vulnerable elderly and need to be emphasized; a) More than $50 \%$ of people over the age of 65 suffer from four to five co-morbid conditions often including cardiac or pulmonary diseases that could complicate the diagnosis of anemia with the signs and symptoms being attributed to the other disease conditions; b) Cognitive impairment in the elderly often leads to problems in obtaining a clear history; c) Presentation of diseases is often atypical in the elderly; d) Older people typically have less hemostatic reserve and a rapid deterioration in clinical status can occur if the diagnosis is delayed; e) There might be limitations in conducting an invasive diagnostic work-up in a frail elderly patient; f) The goal of therapy in older cognitively intact individuals is often to maintain their functional independence and improve their quality of life.

\section{METHODS}

We present a case series of patients between ages 65-99 years who were followed at the Senior Health clinic between 2007 and 2012. Random number generator was used to select 99 charts from an institutional review board (IRB \# 113022) approved data set for seniors with different co-morbid conditions. Charts were reviewed for WHO defined presence of anemia $(\mathrm{Hb}<13$ in men and $<12$ in women). 54/99 patients had WHO defined anemia at some point in a 5 year period.

In-patient and out-patient visits documenting the anemia in these 54 patients were analyzed for the underlying etiology, diagnosis and specific management of anemia. For each case, data collection included problem list, functional capacity, drop in hemoglobin, the level of hemoglobin triggering blood transfusion, pre-transfusion signs/symptoms, hemodynamic instability, functional decline as well as post transfusion benefits or adverse events.

$5 / 54$ cases actually demonstrated scenarios of serious or life-threatening anemia presenting with non-specific signs and symptoms where timely blood transfusion averted serious adverse consequences.

\section{CASE \#1: Dizziness and Weakness}

79 year old African American male with history of Coronary Artery Disease (CAD), Congestive Heart Failure (CHF), Hypertension (HTN), Atrial Fibrillation, status post angioplasty, pacemaker, Implantable Cardioverter Defibrillator (ICD) and Chronic Kidney Disease (CKD) was admitted with complaints of dizziness and weakness after 3 episodes of hematochezia. Patient had undergone a screening colonoscopy a day earlier that had been negative. Admission blood pressure (BP) was 122/71 mmHg (baseline BP 130$140 / 80-90 \mathrm{mmHg}$ ) and heart rate was 88 beats/min. Hb was $12.5 \mathrm{~g} / \mathrm{dl}$. After receiving normal saline, patient's BP returned to baseline but $\mathrm{Hb}$ dropped to $10.2 \mathrm{~g} / \mathrm{dl}$. The second day patient continued to have hematochezia and his $\mathrm{Hb}$ dropped to $8.4 \mathrm{~g} / \mathrm{dl}$. The documentation in the chart indicated that patient was hemodynamically stable and asymptomatic at rest. A decision was made to transfuse 2 units of packed Red Blood Cells (RBC) and 2 units of Fresh Frozen Plasma (FFP). Patient's GI bleeding ceased and $\mathrm{Hb}$ increased to $10.5 \mathrm{~g} / \mathrm{dl}$. There was no need for any surgical intervention and he was discharged home after observation.
Caveats: The "hemodynamic stability" noted in this elderly patient's chart was assessed at rest. This patient was beta-blocked, hence volume depletion and stress-induced responses were likely masked. As per documentation, this patient did not have any presence of hemodynamic instability, nevertheless, timely transfusion in this case very likely averted potential life-threatening cardiovascular consequences and prolonged hospital stay. This case highlights the fact that hemodynamic stability should be assessed appropriately by checking for orthostatic hypotension, tachycardia, weakness, and shortness of breath on exertion because decisions based on assessment of hemodynamic stability in an elderly person at rest could lead to errors in management.

\section{CASE \#2: Dyspnea with COPD Exacerbation}

76 year old African American male with history of HTN, CKD, Chronic Obstructive Pulmonary Disease (COPD) and Diabetes Mellitus (DM) presented to the clinic with 2 weeks history of progressive increase in shortness of breath and fatigue. He had increased his supplemental oxygen to 3 Liters and was still short of breath at rest. He was unable to do any house work and had difficulty preparing meals. He denied having hematochezia, black stools, chest pain and fever. Vital signs on presentation-BP $168 / 58 \mathrm{mmHg}$, pulse: 77 beats/min, respiratory rate: 24 breaths $/ \mathrm{min}$. Initial impression was exacerbation of COPD and he was started on Azithromycin and steroids. However, a Complete Blood Count (CBC) obtained for work-up of pneumonia during the visit revealed a $\mathrm{Hb}$ of $7.4 \mathrm{~g} / \mathrm{dl}$, which had dropped by $2.3 \mathrm{~g} / \mathrm{dl}$ over the past two months. 2 units of packed RBCs were transfused with a subsequent increase in $\mathrm{Hb}$ to $8.7 \mathrm{~g} / \mathrm{dl}$. This resulted in a dramatic improvement in his fatigue and functional status although some degree of dyspnea remained. The cause for the anemia was reactivation of an old peptic ulcer which required treatment.

Caveats: Often shortness of breath can accompany an acute illness or mimic an acute exacerbation of a chronic illness. In elderly patients with multiple serious comorbidities it can trigger an extensive work-up for exploration of cardiovascular or pulmonary etiologies. In the above case, COPD exacerbation was the initial diagnosis as patient's presentation was not suggestive of a GI bleed. This scenario also emphasizes that patients with chronic GI bleed may not present with hemodynamic instability when the rate of blood loss is slow and this may mislead the Provider from considering acute anemia among his/her top differentials. Moreover, in the frail elderly, typical symptoms of anemia can easily be falsely attributed to other co-morbidities.

\section{CASE \#3: Fatigue, Confusion or Delirium}

88 year old Caucasian female with history of HTN, valvular heart disease and transient ischemic attacks developed massive gastrointestinal bleed secondary to Gastric Antral Vascular Ectasia (GAVE) that initially required 6 units of packed red cell transfusions. Subsequently she presented with significant fatigue, dyspnea, weakness, dizziness, with difficulty walking and confusion after recurrent episodes of GI bleeds. Patient usually became symptomatic at $\mathrm{Hb}$ values between 
7.1-8.7 $\mathrm{g} / \mathrm{dl}$ requiring packed $\mathrm{RBC}$ transfusions every 2-6 months for symptom relief. Several Argon Plasma Ablation procedures were performed to control the bleeding with partial success. Patient's frequency of GI bleeds increased \& her packed RBCs requirement increased to every 5-7 days. For past 6 years patient has remained active and cognitively intact with support from out-patient transfusions with a mean post-transfusion $\mathrm{Hb}$ of $10.7 \mathrm{~g} / \mathrm{dl}$. She continued to volunteer in the community, limited only by mild fatigue and weakness. It was notable that the patient always developed delirium with a $\mathrm{Hb}$ less than $8.0 \mathrm{~g} / \mathrm{dl}$. However, because management decisions were always made promptly and efficiently, this patient only required one hospital admission for her symptomatic anemia.

Caveats: This elderly patient was not a candidate for surgical intervention; packed RBC transfusions for her have been a life sustaining measure. It also highlights the point that timely transfusions with packed RBCs can be done safely in the elderly on an out-patient basis. This is likely cost effective in reducing frequent clinic \& emergency room visits as well as hospitalizations for complications related to anemia. Most importantly, this case establishes the fact that in selected transfusion-dependent elderly patients, symptomdriven transfusions can promote functional independence and lead to improved quality of life.

\section{CASE \#4: Fatigue, Weakness, Dyspnea on Exertion and Falls}

89 year old Caucasian male who had a past medical history notable for HTN, Transient Ischemic Attacks, hypothyroidism, dyslipidemia, Restless leg syndrome, hereditary spastic paresis, status post laser prostatectomy, urinary incontinence, status post dilatation of urethral stricture, recurrent bladder/renal stones and intermittent hematuria presented to the clinic with 2 week history of progressively worsening fatigue, weakness, falls and mild dyspnea on exertion. Patient's CBC from 3 days prior was notable for $\mathrm{Hb}$ of $7.3 \mathrm{~g} / \mathrm{dl}$; a drop from $11.4 \mathrm{~g} / \mathrm{dl}$ three months earlier. He was seen in the clinic and was sent to the hospital for urgent blood transfusion. He reported recurrent hematuria but his urinalysis showed only 3-5 RBCs. Patient denied recent history of hematochezia, melena and hematemesis. On admission, his $\mathrm{Hb}$ was further reduced to $6.7 \mathrm{~g} / \mathrm{dl}$ with greater weakness and shortness of breath. On documentation, he remained hemodynamically stable at rest. $\mathrm{He}$ required three units of packed red cells and $\mathrm{Hb}$ the next day at discharge was $8.9 \mathrm{~g} / \mathrm{dl}$. Patient's symptoms of dyspnea and weakness resolved after receiving the blood transfusion with only residual mild fatigue.

Caveats: This is a frail older patient with multiple chronic co-morbidities. His constellation of symptoms was not very prominent because of his limited physical function and even while in hospital he remained "hemodynamically stable". What triggered an evaluation was his falls, which could be attributed to the spastic paralysis but had become more frequent. This patient did not want a GI work-up at that time, so the cause of anemia could not be determined. The transfusions were probably life-saving and significantly improved his quality of life and function.

\section{CASE \#5: Weakness and Shortness of Breath}

$79 \mathrm{y} / \mathrm{o}$ Caucasian male with past medical history notable for HTN, Alzheimer's dementia, dyslipidemia, depression, Gastroesophageal Reflux Disease, Obstructive Sleep Apnea (OSA) and recurring GI bleeds presented to the Emergency Room with weakness and black stools. His BP and pulse were $80 / 43 \mathrm{mmHg}$ and 82 beats/min respectively and $\mathrm{Hb}$ level was $8.8 \mathrm{~g} / \mathrm{dl}$ on presentation. Patient's symptoms resolved and BP stabilized after 3 units of packed cell transfusion. $\mathrm{Hb}$ recovered to $12.7 \mathrm{~g} / \mathrm{dl}$ post-transfusion. Except for minimal esophagitis and villous adenoma, Esophagogastroduodenoscopy (EGD) and colonoscopy were unrevealing. Three months prior to this episode the patient had presented with significant shortness of breath, vomiting and diarrhea and a history of black stools. He was afebrile on presentation with a BP of 104/52 $\mathrm{mmHg}$. Hb was $12 \mathrm{~g} / \mathrm{dl}$ and White Blood Cell (WBC) count was $19,000 / \mathrm{mm}^{3}$. CT chest, abdomen and pelvis were unremarkable and WBC scan did not reveal any abscess. Patient's lowest recorded $\mathrm{Hb}$ during that admission was $8.9 \mathrm{~g} / \mathrm{dl}$ and he received a unit of blood. Weakness and shortness of breath resolved as $\mathrm{Hb}$ improved. EGD showed a Mallory Weiss tear, severe esophagitis and a duodenal ulcer.

Caveats: It is noteworthy that this patient presented with acute anemia secondary to GI bleed that was symptomatic at a hemoglobin level greater than the recommended transfusion threshold. Also, transfusion averted significant morbidity and led to a short hospital stay. This patient was cognitively impaired and did not complain of gastric/ esophageal pain, however, a complete work-up revealed a reversible, life-threatening cause of anemia and timely transfusion averted a worse outcome.

\section{Statistical Analysis}

The difference in hemoglobinpre and post-transfusion was significant with $p<0.03$ (Mann-Whitney $U$ test), as shown in Fig. (1). The total number of non-specific symptoms experienced by the patients pre-transfusion was 19 and post-transfusion was 5, which was also significantly different with $\mathrm{p}<0.01$ (Mann-Whitney $U$ test), as shown in Fig. (2).

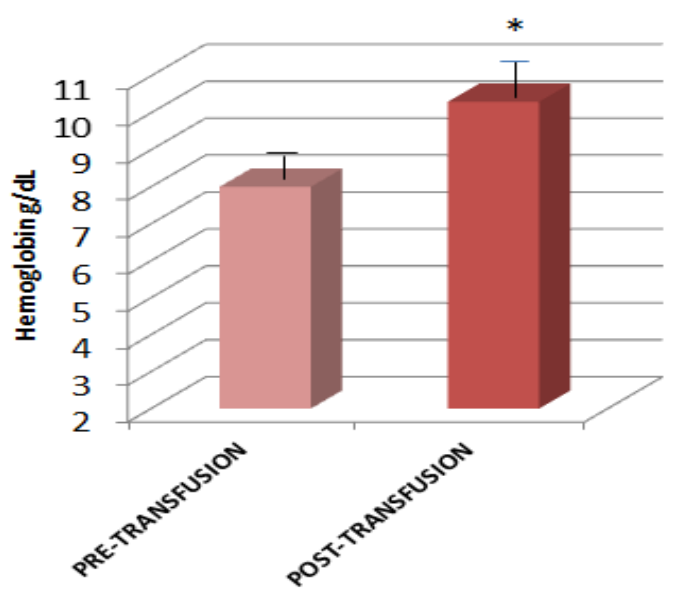

Fig. (1). Hemoglobin value in anemic subjects before and after blood transfusion/ 


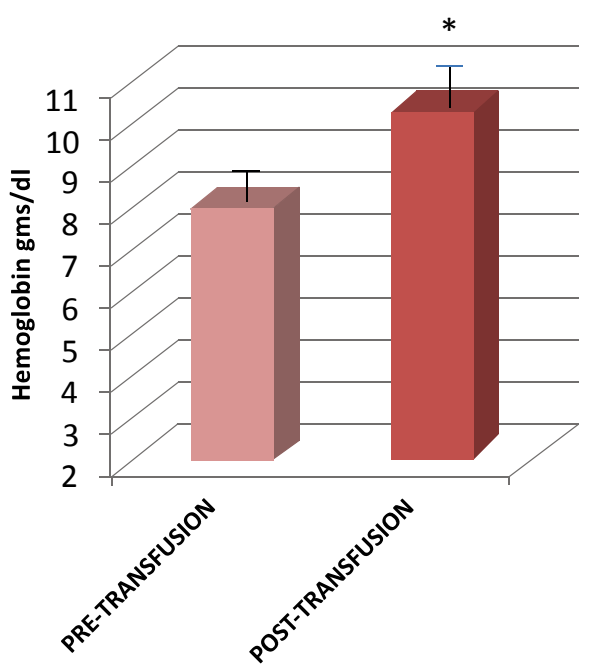

Fig. (2). Symptom score in anemic subjects before and after blood transfusion.

\section{DISCUSSION}

The cases described above illustrate the point that AABB transfusion guidelines cannot be adopted as a standard for all anemic patients especially the geriatric population in whom serious anemia often presents with non-specific or vague symptoms requiring transfusion at a higher hemoglobin level than recommended. Better recognition of the signs and symptoms of anemia is needed in the elderly in whom symptoms are often attributed to aging or other disease comorbidities. Symptomatology and severity of anemia can be masked in the elderly because of a reduced level of activity. Management decisions based on signs and symptoms of anemia should involve functional assessment of the elderly subject.

In 2000, there were 35 million people over the age of 65 in the United States. This age group is expected to increase to 80 million by year 2050 . The greatest increase of approximately 5 foldis expected in the age cohort of 85 years and older. Thus the impact of chronic diseases and associated disability in the elderly will have great implications for healthcare in the coming decades. Anemia is now being recognized as one of the common conditions that must be addressed more vigorously, both in the out-patient and in-patient environment, to reduce the burden of morbidity and mortality and improve quality and quantity of life of the aging strata of our society. In the past 2 decades a number of studies have been conducted to assess the impact of anemia on the elderly (Table 1), and the major findings of some of these studies are discussed below.

\section{Anemia and Mortality}

Anemia amongst older adults (over the age of 65) also increases the risk of hospitalization and mortality. A recent large Canadian study of over 17000 older adults (66 years and older) showed a significant association between anemia and risk of hospitalization secondary to all causes, including cardiovascular related hospitalization and all-cause mortality [8]. Likewise a European study of 4500 adults between ages
65-84 years also revealed increased likelihood of hospital admissions and all-cause mortality of anemic patients versus non-anemic patients after controlling for many possible variables [2]. Other prospective studies from Europe and USA have also shown a statistically significant association between anemic elderly and increased risk of hospitalization and mortality [2, 9-11]. Among hospitalized anemic patients, studies have shown an increased likelihood of delirium, mobility disability and falls that often results in prolonged in-patient course.

\section{Anemia and Delirium}

Delirium, a clinical syndrome that is defined as inattention and acute cognitive dysfunction affects an estimated $14-56 \%$ of all hospitalized elderly patients [12-18]. At least $50 \%$ of geriatric patients hospitalized annually in the US develop complications secondary to delirium with a mortality rate between $25-33 \%[12,13]$.

Among older surgical patients, post-operative delirium is seen in $15-53 \%$ and its incidence is as high as $70-87 \%$ in elderly Intensive Care Unit patients [14]. Delirium is associated with worse outcomes, extended hospitalizations, higher costs, cognitive decline and increased mortality rates [12-15]. Some of the important risk factors for delirium in the elderly are dementia, male sex, high burden of comorbidities, certain medications, sensory impairment, sleep deprivation, metabolic derangements and pain [14]. Recent available studies have shown that anemia significantly and independently increases the likelihood of delirium in the ward, medical \& surgical ICUs as well as post-operative settings. In our particular case study (subject \# 3), the patient only developed delirium when $\mathrm{Hb}$ dropped below $8 \mathrm{~g} / \mathrm{dl}$, but she was otherwise cognitively intact and had age-appropriate functional capacity. It is likely that patients with some element of dementia or hypoxemia could develop confusion at higher $\mathrm{Hb}$ levels.

In a small 5 month prospective study of 190 elderly patients (mean age, 82 years) performed in a Belgian hospital geriatric ward, $18 \%$ were identified with delirium. It was significantly more frequent among male patients in comparison to female patients. Results showed maximum number of delirious patients (among both men and women) in the quartile with lowest $\mathrm{Hb}$ i.e. $<10.8 \mathrm{~g} / \mathrm{dl}$. Statistical analysis with adjustment for major confounding factors showed anemic men but not anemic women to have a high likelihood of becoming delirious and this likelihood increased with decreasing $\mathrm{Hb}$ concentration [16]. Similarly another study conducted in a Swedish hospital ICU showed that patients with moderate and severe delirium had lower $\mathrm{Hb}$ concentrations $(6-9.5 \mathrm{~g} / \mathrm{dl})$ in comparison to those with no symptoms of delirium [17].

Anemia was also found to independently increase the risk of delirium after cardiac surgery in a recent Polish study [18]. The authors postulated that factors such as atrial fibrillation and hypoxia were the likely cause of cerebral hypoxemia, inhibiting the formation of neurotransmitters and resulting in decreased cholinergic and glutaminergic activities in the cerebral cortex resulting in delirium [18]. 
Table 1. Studies on impact of anemia in elderly.

\begin{tabular}{|c|c|c|c|c|c|}
\hline \multirow[t]{2}{*}{ Delirium } & $\begin{array}{l}\text { Joosten et al. } \\
\text { Belgium } \\
2006^{a}\end{array}$ & $\begin{array}{l}\text { Longitudinal } \\
\text { prospective } \\
\text { study over } 5 \\
\text { months }\end{array}$ & $\begin{array}{l}190 \text { elderly patients in } \\
\text { acute geriatric ward. } \\
\text { Mean age of the group } \\
\text { was } 82.5 \text { yrs }\end{array}$ & $\begin{array}{l}\text { Study patients investigated } \\
\text { with Mini Mental Status } \\
\text { Exam (MMSE), } \\
\text { Confusion Assessment } \\
\text { Method (CAD), } \\
\text { demographic, clinical and } \\
\text { lab data }\end{array}$ & $\begin{array}{l}18 \% \text { of the patients identified by delirium. } \\
50 \% \text { of patients had anemia. } \\
\text { Anemia, male sex, age }>82 \mathrm{yrs} \text {, } \\
\text { dehydration and dementia were } \\
\text { independent risk factors for delirium. }\end{array}$ \\
\hline & $\begin{array}{l}\text { Axell et al. } \\
\text { Sweden } \\
2002^{b}\end{array}$ & $\begin{array}{l}\text { Longitudinal } \\
\text { prospective } \\
\text { study: } \\
\text { Data } \\
\text { collected over } \\
6.5 \text { months }\end{array}$ & $\begin{array}{l}19 \text { ventilated patients in } \\
\text { Intensive Care Unit } \\
\text { (ICU) } \\
\text { Median age } 70 \text { yrs }\end{array}$ & $\begin{array}{l}\text { Study patients had an ICU } \\
\text { stay length of }>36 \text { hrs and } \\
\text { were closely observed } \\
\text { during the stay. Patients } \\
\text { were interviewed in depth } \\
\text { twice after discharge. }\end{array}$ & $\begin{array}{l}6 \text { patients had severe delirium } \& 8 \\
\text { moderate delirium. } \\
\text { Severity of delirium was associated with } \\
\text { the degree of anemia. Patients with severe } \\
\text { delirium had significantly lower } \mathrm{Hb}(7.5- \\
9.5 \mathrm{~g} / \mathrm{dl}) . \\
\text { Patients with severe delirium required } \\
\text { higher doses of fentanyl and midazolam } \\
\text { and a longer duration of ventilation \& ICU } \\
\text { stay. }\end{array}$ \\
\hline \multirow[t]{2}{*}{ Dementia } & $\begin{array}{l}\text { Hong et al. } \\
\text { S. Korea\& } \\
\text { USA } \\
2013{ }^{c}\end{array}$ & $\begin{array}{l}\text { Prospective } \\
\text { Cohort Study: } \\
\text { data collected } \\
\text { over } 11 \text { years } \\
\text { of follow up }\end{array}$ & $\begin{array}{l}2552 \text { community } \\
\text { dwelling, ethnically } \\
\text { diverse. } \\
\text { Mean age: } 76.1 \text { yrs. } \\
\text { Memphis TN \& } \\
\text { Pittsburgh Pennsylvania. }\end{array}$ & $\begin{array}{l}\text { Cognitive function } \\
\text { assessed at } 1,3,5,8,10,11 \\
\text { years with a global test }\end{array}$ & $\begin{array}{l}2552 \text { subjects; } 51.8 \% \text { female, } 38.9 \% \text { were } \\
\text { black. } 393(15.4 \%) \text { had anemia at baseline } \\
\text { and } 455(17.4 \%) \text { developed dementia. } \\
\text { Older adults with anemia at baseline had a } \\
\text { higher risk of developing dementia } \\
(22.7 \%) \text { as compared to those who did not } \\
\text { have anemia (17\%) } \\
\text { After adjusting for age, race, sex, } \\
\text { education, literacy, APOE } \varepsilon 4 \text { status, mini- } \\
\text { mental status exam, co-morbidities } \\
\text { (stroke, HTN, DM and Myocardial } \\
\text { Infarction), renal function, indices of } \\
\text { anemia indices \& C-Reactive Protein, the } \\
\text { results remained statistically significant. }\end{array}$ \\
\hline & $\begin{array}{l}\text { Shah et al. } \\
\text { IL USA } \\
2011^{d}\end{array}$ & $\begin{array}{l}\text { Prospective } \\
\text { study: } \\
\text { participants } \\
\text { followed for } \\
3.3 \text { yrs }\end{array}$ & $\begin{array}{l}881 \text { community } \\
\text { dwelling: } \\
\text { Mean age; } 80.1 \text { yrs } \\
\text { Chicago, IL. }\end{array}$ & $\begin{array}{l}\text { Cognitive decline assessed } \\
\text { over a period of } 3 \text { years in } \\
\text { participants of the Rush } \\
\text { Memory and Aging } \\
\text { project who did not have } \\
\text { dementia. }\end{array}$ & $\begin{array}{l}\text { Follow up over a period of approximately } \\
\text { three years was notable for development } \\
\text { of dementia in } 113 \text { patients. } \\
\text { Those who developed dementia were of } \\
\text { older age and had poorer performance on } \\
\text { MMSE. Their BMI and cognitive function } \\
\text { were also relatively lower. In comparison } \\
\text { to individuals without dementia, those } \\
\text { with dementia were more likely to be } \\
\text { depressed and had a smaller social circle. } \\
\text { Subjects with Hb of } 13.7 \mathrm{~g} / \mathrm{dl} \text { had the } \\
\text { smallest rate of cognitive decline. Anemic } \\
\text { participants had a faster decline in } \\
\text { cognitive function in comparison to those } \\
\text { without anemia. }\end{array}$ \\
\hline
\end{tabular}




\begin{tabular}{|c|c|c|c|c|c|}
\hline $\begin{array}{c}\text { Conditions } \\
\text { Associated } \\
\text { with Anemia }\end{array}$ & Study & $\begin{array}{c}\text { Type \& } \\
\text { Duration of } \\
\text { Study }\end{array}$ & Sample Size \& Age & Methodology & Results \\
\hline & $\begin{array}{l}\text { Atti et al. } \\
\text { Sweden \& } \\
\text { Italy } \\
2005^{\text {e }}\end{array}$ & $\begin{array}{l}\text { Prospective } \\
\text { study } \\
\text { (Kungsholman } \\
\text { project); } \\
\text { Subjects' data } \\
\text { analyzed at } \\
\text { baseline and at } \\
3 \text { years. }\end{array}$ & $\begin{array}{l}1435 \text { subjects without } \\
\text { dementia. } \\
\text { Age range: } 75-95 \text { years }\end{array}$ & $\begin{array}{l}\text { Comparison of data at } \\
\text { baseline to } 3 \text { year follow up. }\end{array}$ & $\begin{array}{l}\text { At the end of } 3 \text { years, anemic patients with } \\
\text { normal cognition had a two times higher risk } \\
\text { of developing dementia than cognitively } \\
\text { intact non-anemic patient after adjustment for } \\
\text { gender, age and education. } \\
\text { The association between anemia and } \\
\text { development of dementia remained } \\
\text { unchanged even after adjusting for chronic } \\
\text { disease, inflammation and nutritional status. } \\
189 \text { subjects were diagnosed with dementia on } \\
\text { follow up at } 3 \text { years; } 77.2 \% \text { were diagnosed } \\
\text { with AD and } 12.7 \% \text { with Vascular dementia. } \\
\text { After adjusting for age, gender and level of } \\
\text { education, subjects with anemia were two } \\
\text { times more likely to develop AD. }\end{array}$ \\
\hline $\begin{array}{c}\text { Decline in } \\
\text { Physical } \\
\text { Performance }\end{array}$ & $\begin{array}{l}\text { Thein et al. } \\
\text { USA } \\
2009\end{array}$ & $\begin{array}{l}\text { Multi-center } \\
\text { cross-sectional } \\
\text { survey } \\
\text { performed } \\
\text { over one year. }\end{array}$ & $\begin{array}{l}328 \text { patients: mean age } \\
76.8 \text { year }\end{array}$ & $\begin{array}{l}\text { Three sites participated. } \\
\text { Instruments used: SF- } 36 \text { \& } \\
\text { Functional Assessment of } \\
\text { Chronic Illness Therapy- } \\
\text { Anemia (FACIT-An), } \\
\text { IADL, GDS \& Handgrip } \\
\text { strength. Questionnaires and } \\
\text { measurements performed } \\
\text { within } 1 \text { month of serum } \mathrm{Hb} \\
\text { measurement. }\end{array}$ & $\begin{array}{l}68 \% \text { were women; age ranged from } \\
65-103 \text { yrs } \\
\text { Older patients ( } 75 \mathrm{yrs} \text { and above) had a lower } \\
\text { mean Hb level ( } 12.8 \mathrm{~g} / \mathrm{dl}) \text { in comparison to } \\
\text { the younger (age range } 65-74 \text { yrs) patients } \\
\text { whose mean } \mathrm{Hb} \text { level was } 13.3 \mathrm{~g} / \mathrm{dl} \text {. } \\
90(27 \%) \text { patients had WHO defined anemia: } \\
54 \text { females and } 36 \text { ( } 31 \%) \text { males. } \\
\text { There was almost a } 10 \text { point difference in the } \\
\text { unadjusted mean SF-36 scores of patients } \\
\text { with Hb of } 15 \mathrm{~g} / \mathrm{dl}(47.1) \text { and those with Hb } \\
\text { less than } 12 \mathrm{~g} / \mathrm{dl}(37.3) \text {. This decreasing trend } \\
\text { was evident across all Hb groups as well as } \\
\text { the five physical function subscales. }\end{array}$ \\
\hline & $\begin{array}{l}\text { Penninx et al. } \\
\text { Italy } \\
2004^{\mathrm{f}}\end{array}$ & $\begin{array}{l}\text { Cross- } \\
\text { sectional study } \\
\text { over18 months }\end{array}$ & $\begin{array}{l}1008 \text { participants: mean } \\
\text { age } 75.4 \text { years }\end{array}$ & $\begin{array}{l}\text { Debility in } 6 \text { activities of } \\
\text { daily living \& } 8 \\
\text { instrumental activities of } \\
\text { daily living. SF } 36, \text { knee } \\
\text { extensor and handgrip } \\
\text { strength assessments. }\end{array}$ & $\begin{array}{l}\text { Men had an average } \mathrm{Hb} \text { level of } 14.4 \mathrm{~g} / \mathrm{dl} \text { and } \\
\text { women's mean } \mathrm{Hb} \text { level was } 13.2 \mathrm{~g} / \mathrm{dl} \text {. } \\
11.3 \% \text { of the participants were anemic. } \\
\text { Subjects with anemia had lower scores on SF } \\
36 \text {, decreased handgripand knee extensor } \\
\text { strength when compared to subjects without } \\
\text { anemia. }\end{array}$ \\
\hline & $\begin{array}{l}\text { Penninx et al. } \\
\text { USA } \\
2003\end{array}$ & $\begin{array}{l}\text { Prospective } \\
\text { cohort study } \\
\text { over } 4 \text { yrs. }\end{array}$ & $\begin{array}{l}1146 \text { subjects: mean age: } \\
77 \text { yrs }\end{array}$ & $\begin{array}{l}\text { Evaluation of balance, a } \\
\text { timed } 2.4-\mathrm{m} \text { walk, and a } \\
\text { timed test of five chair rises } \\
\text { for assessment of physical } \\
\text { function; these were } \\
\text { incorporated into scale: } 0 \\
\text { (poor) to } 12 \text { (excellent) }\end{array}$ & $\begin{array}{l}\text { There was a significant association between } \\
\text { anemia and mean decline in physical function } \\
\text { over a period of } 4 \text { years; } 2.3 \text { in anemic } \\
\text { subjects and } 1.4 \text { non-anemic subjects } \\
\text { ( } \mathrm{P}=0.003) \\
\text { This association between anemia and } \\
\text { increased functional decline was also seen in } \\
\text { participants without chronic illnesses } \\
\text { associated with anemia (malignancy, } \\
\text { infectious disease and renal insufficiency) } \\
\text { and after adjusting for lipid, iron and albumin } \\
\text { levels. } \\
\text { Subjects with borderline anemia, a Hb level } \\
\text { within } 1 \mathrm{~g} / \mathrm{dL} \text { over the WHO defined anemia, } \\
\text { also showed a higher mean physical decline } \\
(1.8) \text { vs those with greater Hb levels } \\
(\mathrm{P}=0.02) \text {. }\end{array}$ \\
\hline
\end{tabular}




\begin{tabular}{|c|c|c|c|c|c|}
\hline $\begin{array}{c}\text { Conditions } \\
\text { Associated } \\
\text { with Anemia }\end{array}$ & Study & $\begin{array}{l}\text { Type \& } \\
\text { Duration of } \\
\text { Study }\end{array}$ & Sample Size \& Age & Methodology & Results \\
\hline \multirow[t]{4}{*}{$\begin{array}{l}\text { Hospital- } \\
\text { ization } \\
\quad \& \\
\text { Mortality }\end{array}$} & $\begin{array}{l}\text { Culleton } \\
\text { et al. } \\
\text { Canada } \\
2006^{\mathrm{g}}\end{array}$ & $\begin{array}{l}\text { Prospective } \\
\text { cohort study } \\
\text { over } 3 \text { yrs }\end{array}$ & $\begin{array}{l}17030 \text { community } \\
\text { dwelling subjects: } \\
\geq 66 \text { yrs }\end{array}$ & $\begin{array}{l}\text { Cox potential analyses } \\
\text { performed to assess } \\
\text { associations between } \\
\text { anemia (defined as HB } \\
\text { less than } 11 \mathrm{mg} / \mathrm{dl} \text { ) and } \\
\text { hemoglobin and all-cause } \\
\text { mortality. }\end{array}$ & $\begin{array}{l}1983 \text { mortalities and } 7278 \text { first } \\
\text { hospitalizations were recorded. } \\
\text { Analysis showed a higher risk of } \\
\text { mortality, first all-cause hospitalization, } \\
\text { and first hospitalization for cardiovascular } \\
\text { causes (HR, } 2.49 ; 95 \% \text { ) in anemic patients } \\
\text { with normal kidney function. } \\
\text { The association between Hb and all-cause } \\
\text { mortality was evident as an inverse } \\
\text { J-Shaped curve. Women with Hb level } \\
13-15 \mathrm{mg} / \mathrm{dl} \text { and men with Hb level } \\
\text { between } 14-17 \mathrm{mg} / \mathrm{dl} \text { had the smallest risk } \\
\text { for mortality. }\end{array}$ \\
\hline & $\begin{array}{l}\text { Riva et al. } \\
\text { Italy } \\
2009^{\mathrm{h}}\end{array}$ & $\begin{array}{l}\text { Prospective } \\
\text { population } \\
\text { based study } \\
\text { over } 4 \text { years }\end{array}$ & $\begin{array}{l}7536 \text { elderly with mean } \\
\text { age between } \\
73.6-74.9 \mathrm{yrs}\end{array}$ & $\begin{array}{l}\text { Data from } 7536 \text { elderly } \\
\text { utilized to determine } \\
\text { mortality. Complete health } \\
\text { information available for } \\
4501 \text { subjects. }\end{array}$ & $\begin{array}{l}\text { There was an increased risk of } \\
\text { hospitalizationand mortality in the elderly } \\
\text { subjects with mild anemia versus subjects } \\
\text { who did not have anemia. }\end{array}$ \\
\hline & $\begin{array}{l}\text { Denny et al } \\
\text { NC USA } \\
2006^{\mathrm{i}}\end{array}$ & $\begin{array}{l}\text { Prospective } \\
\text { cohort study }\end{array}$ & $\begin{array}{l}1744 \text { community } \\
\text { dwelling elderly: mean } \\
\text { age: } 78 \text { yrs }\end{array}$ & $\begin{array}{l}\mathrm{Hb} \text { assessed at baseline. } \\
\text { Physical performance, } \\
\text { using Katz, IADL and } \\
\text { cognition using Sort } \\
\text { Portable Mental Status } \\
\text { Questionnaire were } \\
\text { assessed at baseline and } 4 \\
\text { year follow up interview. }\end{array}$ & $\begin{array}{l}33 \% \text { of women and } 31 \% \text { of men had } \\
\text { anemia. Anemic subjects were of older age } \\
\text { more often had African American } \\
\text { ethnicity, were less educated, had } \\
\text { suboptimal kidney function and a } \\
\text { hospitalization in the previous year. } \\
\text { Caucasians in all age cohorts assessed had } \\
\text { a higher Hb level in comparison to their } \\
\text { African American age cohorts. } \\
\text { A statistically significant rise in mortality } \\
\text { was observed in all subjects with anemia } \\
\text { in comparison to those without anemia. } \\
\text { This was unchanged even after adjusting } \\
\text { for sex. } \\
\text { At } 8 \text { years, women with Hb level between } \\
13 \text { and } 14 \mathrm{~g} / \mathrm{dl} \text { men with hemoglobin level } \\
\text { between } 14 \text { and } 15 \mathrm{~g} / \mathrm{dl} \text { had the greatest } \\
\text { survival percentage. The lowest rate of } \\
\text { survival was notable in Hb levels at both } \\
\text { extremes. }\end{array}$ \\
\hline & $\begin{array}{l}\text { Penninx } \\
\text { et al. USA } \\
2006^{\mathrm{j}}\end{array}$ & $\begin{array}{l}\text { Longitudinal } \\
\text { prospective } \\
\text { study over } 4 \\
\text { years }\end{array}$ & $\begin{array}{l}3607 \text { participants of } \\
\text { EPESE study with mean } \\
\text { age of } 78 \text { years }\end{array}$ & $\begin{array}{l}\text { Anemia as per WHO } \\
\text { criteria. Data regarding } \\
\text { death and hospital } \\
\text { admissions over } 4 \text { years } \\
\text { accessed from death } \\
\text { records and the Medicare } \\
\text { database. }\end{array}$ & $\begin{array}{l}12.5 \% \text { of the subjects had anemia. } \\
\text { Participants with anemia had a greater } \\
\text { likelihood of death and hospitalization } \\
\text { than those without anemia in the follow-up } \\
\text { period. } \\
\text { After adjusting for demographics and co- } \\
\text { morbid illnesses, anemia was found to } \\
\text { have statistically significant association } \\
\text { with subsequent death and hospitalization. } \\
\text { Anemia alsoshowed a statistically } \\
\text { significant association with mortality and } \\
\text { hospitalization in participants without co- } \\
\text { morbidities at baseline. }\end{array}$ \\
\hline
\end{tabular}




\begin{tabular}{|c|c|c|c|c|c|}
\hline $\begin{array}{c}\text { Conditions } \\
\text { Associated } \\
\text { with Anemia }\end{array}$ & Study & $\begin{array}{c}\text { Type \& } \\
\text { Duration of } \\
\text { Study }\end{array}$ & Sample Size \& Age & Methodology & Results \\
\hline Mortality & $\begin{array}{l}\text { Elzen } \text { et al. } \\
\text { Netherlands } \\
2009^{k}\end{array}$ & $\begin{array}{l}\text { Longitudinal } \\
\text { prospective } \\
\text { study (Leiden } \\
85 \text {-plus } \\
\text { Study): } \\
\text { patients } \\
\text { followed over } \\
5 \text { years }\end{array}$ & $\begin{array}{l}562 \text { people } \\
\text { Age: } 85 \text { years }\end{array}$ & $\begin{array}{l}\text { Anemia per WHO } \\
\text { definition. } 3 \text { aspects of } \\
\text { functional state assessed at } \\
\text { baseline and once every } \\
\text { year for } 5 \text { years: debility } \\
\text { in basic and instrumental } \\
\text { activities of daily living, } \\
\text { cognitive function and } \\
\text { presence of low mood. } \\
\text { Data on death accessed } \\
\text { from the municipal } \\
\text { registry. }\end{array}$ & $\begin{array}{l}26.7 \% \text { of the elderly participants had } \\
\text { anemia at baseline. } \\
\text { At baseline, anemic subjectshad greater } \\
\text { debility in physical function, lower } \\
\text { cognitive function and more symptoms of } \\
\text { depression than the non-anemic } \\
\text { participants. These differences were not } \\
\text { significantafter adjustment for comorbid } \\
\text { illnesses. } \\
\text { On subsequent follow up, anemia was } \\
\text { associated with a decrease in Instrumental } \\
\text { Activities of Daily Living, which } \\
\text { remained significant after adjusting for } \\
\text { comorbid conditions. } \\
\text { Subjects in whom new onset of anemia } \\
\text { was found on follow up ( } \mathrm{n}=99 \text { ) also had } \\
\text { an increase in disability. } \\
\text { Both categories of anemia patients, new- } \\
\text { onset and previous diagnosis, had higher } \\
\text { mortality rates after adjusting for various } \\
\text { demographical variables including } \\
\text { education level, gender, socioeconomic } \\
\text { status, and other variables (living in long- } \\
\text { term care facility, CRP level, creatinine } \\
\text { clearance and disease status) }\end{array}$ \\
\hline
\end{tabular}

Letters referring to numbered references in text as follows: $a=16, b=17, c=19, d=21, e=20, f=23, g=8, h=2, i=9, j=10, k=11$.

\section{Anemia and Dementia}

In the last decade there has been mounting evidence linking anemia to the risk of developing dementia. The most recent prospective cohort study investigating this link was published in August 2013 and involved 2552 community dwelling older adults. Participants were followed over a period of 11 years. Cognitive function was evaluated at years $1,3,5,8,10$ and 11 with Modified Mini Mental Status (3MS) examination. Dementia diagnosis was established by review of hospital records, prescription of dementia medication or a race stratified decline in $3 \mathrm{MS}$ score of more than 1.5 SD from baseline mean. 15.4\% (393/2552) of the subjects had anemia at baseline. Over 11 years, $17.8 \%$ $(455 / 2552)$ were diagnosed with dementia. Older adults with anemia at baseline were more likely to develop dementia $(\mathrm{n}=89,22.7 \%)$ compared to those who were not anemic $(\mathrm{n}=366,17 \%)(\mathrm{p}=0.007)$. This association between anemia and incident dementia retained its statistical significance after accommodating for various potential confounders (age, sex, race, education, literacy, APOE $\varepsilon 4$ status, $3 \mathrm{MS}$ score, and co-morbidities: stroke, HTN, DM, MI, anemia parameters: MCV, RDW, erythropoietin, renal function and CRP) [19]. Two other prospective studies have also shown a statistically significant association between anemia and risk of developing dementia [20,21].

The mechanisms explaining this association have not been well delineated to date. However, several hypotheses have been suggested including impairment of cerebral perfusion and a sudden decrease in oxygenation of the brain leading to a poor cognitive performance. In chronic anemia, poor cerebral oxygenation places the individual at increased risk of developing dementia [20]. The role of erythropoietin in the pathogenesis of dementia is also an area of developing interest. In animal models of stroke and hypoxia, erythropoietin has been shown to have a protective effect. Hence, it has been hypothesized that lower erythropoietin levels as seen in chronic kidney disease may enhance the likelihood of neurodegenerative process. Iron and vitamin B12 deficiencies have also been thought to contribute to poor oxygenation of the brain and cognitive decline [19].

\section{Anemia and Decline in Physical Function}

Mobility impacts functional independence. When mobility disability (difficulty performing such tasks in one's own environment) occurs in the elderly, it inadvertently leads to loss of autonomy, institutionalization and mortality. Anemia is also a significant predictor for functional decline. Recent data from 633 communitydwelling women, from the Woman's Health and Aging Study (WHAS) I \& II showed that even with mild anemia there was an increase in mobility disability risk [22]. In the WHAS, similar findings were also observed between $\mathrm{Hb}$ levels and objective mobility performance as assessed by the Short Physical Performance Battery (SPPB) index. Results showed that the proportion of older women with best SPPB scores had the highest $\mathrm{Hb}$ (13-13.9 g/dL) and those with the worst scores had $\mathrm{Hb}$ concentration in the range $10-12 \mathrm{~g} / \mathrm{dl}$.

Further, a prospective study of 1146 older candidates (mean age, $77 \pm 5$ years: $70 \%$ female) participating in the 
Established Populations for Epidemiologic Study of the Elderly (EPESE) reported that older men and women with anemia experienced clinically significant mobility decline as compared to their non-anemic counterparts, even after adjustment for major confounders [22].

Studies have also shown that anemia interacts with comorbidities that are common in older adults to synergistically increase the risk of outcomes such as frailty and mortality. The independent contribution and impact of anemia on frailty was investigated in a cross-sectional study that examined data from the Women's Health and Aging Study (WHAS) I \&II. In this study, definition of frailty was as pre-established criteria with presence of 3 of 5 manifestations: shrinkage, slow gait speed, weakness, exhaustion and decreased physical activity. The relationship between frailty and anemia was observed as a reverse $J$ curve comparable to the documented association of anemia with mobilitydisability and mortality. The lowest incidence of frailty was observed at mid-normal $\mathrm{Hb}$ levels around $13.5 \mathrm{~g} / \mathrm{dl}$. Frailty was 2.8 times more likely at $\mathrm{Hb}$ level of $11 \mathrm{~g} / \mathrm{dl}$ and 1.5 times more likely at a Hb level of $12 \mathrm{~g} / \mathrm{dl}$ versus $13.5 \mathrm{~g} / \mathrm{dl}$.

The link between anemia and muscle strength was analyzed in a cross-sectional study that studied data from 1008 community dwelling older men and women, age $75.4 \pm 7.3$ years participating in the Aging in the Chianti Study. In this study, older adults with anemia had significant decrease in grip and quadriceps strength even after adjustment for major confounders. A positive relationship has been shown to exist between hemoglobin levels and muscle strength, especially knee extensors and grip strength [22].

In all of the cases that we presented, patients were discharged home fairly rapidly upon improvement of their symptoms although an appropriate assessment of physical function pre-discharge was not done. It is understandable that fatigue and weakness takes time to abate and supplementation with oral iron therapy helps achieve that goal. It is important that the functional status of an older person be assessed not only pre- and post-transfusion, but also periodically during their rehabilitation, since anemia can adversely impair the process of recovery. A hypothesis supporting the causal association between anemia and unfavorable functional outcomes suggests that anemia might limit the maximal and sub-maximal aerobic exercise capacity resulting in exercise intolerance or behavioral modifications (such as decrease in physical activity) that further promotes deconditioning. In turn, anemia-related chronic physical deconditioning could contribute to decrease in muscle mass, strength and quality (sarcopenia and dynapenia), osteoporosis, autonomic dysregulation, executive dysfunction and accelerated renal functional decline. At the cellular level, anemia decreases the oxygen carrying capacity of the blood with chronic tissue hypoxia, and limits the homeostatic responses to acute and chronic stressors, which is the hallmark of frailty $[23,24]$.

\section{Common Types of Anemia in the Elderly}

According to the data from NHANES III, anemia among older adults in the United States is attributable to nutritional deficiencies (Iron, Vitamin B12 and Folate) in 34\%, chronic diseases in $20 \%$, and remains unexplained despite exhaustive work up in $34 \%$ of the cases [25]. Among the nutritional group, iron deficiency anemia (IDA) by itself or concomitantly with folate or B12 deficiency constitutes more than one half of this group [26].

Etiology of IDA among elderly in the developed world is less often secondary to inadequate dietary intake and more frequently from chronic gastrointestinal blood loss [25]. In $40-60 \%$ of the patients, the etiology is the upper GI tract (related to Peptic Ulcer Disease (PUD), esophagitis, gastritis, NSAIDs use, and angiodysplasia) and in $15-30 \%$ it is the colon (lesions being colorectal cancer, premalignant polyps \&angiodysplasia). Dietary inadequacies, Helicobacter pylori infection, malabsorption secondary to atrophic gastritis and rarely celiac disease account for the remaining percentage of IDA in elderly population [27].

\section{Approach Towards the Diagnosis of Iron Deficiency Anemia in the EIderly}

History: When evaluating a person for iron deficiency anemia, it is important to inquire about any known history of PUD, bleeding disorders, celiac disease, Abdominal Aortic Aneurysm and gastric bypass surgery. Patients' dietary habits should also be assessed. Strictly vegan diet can result in iron deficiency as iron from meat, poultry and fish, all sources of heme iron, is absorbed two to three times more efficiently than iron from plant sources (fortified cereals, some beans and spinach). It is also important to know about patients' alcohol, tea/coffee consumption. Excessive alcohol intake can result in iron deficiency anemia by inhibiting binding of iron into heme molecules of Red Blood Cells and by potentially causing GI blood loss [28]. Coffee and tea contain tannins and polyphenols that decrease iron absorption in the gut, hence, increase intake of these beverages contributes to IDA [27].

Physical examination: IDA often presents with nonspecific signs and symptoms. A patient with IDA is likely to report varying degree of dizziness, light-headedness, easy fatigability, tiredness or weakness. Depending on severity, anemia can manifest as postural hypotension, tachycardia, pallor, koilonykia, decreased muscle strength, headaches and/or confusion. In addition, the signs and symptoms of anemia in the elderly are often masked by other co-morbid conditions common in this population, which make the diagnosis more challenging. Some common conditions that can be mistaken for anemia or are frequently encountered co-morbidities in the elderly are listed in Fig. (3). Adverse effects of medications should also be considered in all older patients because of issues associated with polypharmacy and the erosive effects on the gut of some over-the-counter drugs such as NSAIDs. It is also important that vital signs and the cardiopulmonary responses of the patients are determined during activity as well as rest. An older person, who might appear hemodynamically stable in bed, could have chest pain, shortness of breath, tachycardia and severe weakness upon arising from bed and walking around the room (Fig. 3). This would call for a re-evaluation of the decision to transfuse the patient, who otherwise might have been discharged in a borderline unstable condition. Hence, the importance of a functional evaluation in an older adult cannot be over-emphasized. 


\section{Physical and functional assessment of iron deficiency anemia in an older adult}

\section{Ask patient if he/she has:}

- Confusion

- Headaches/dizziness

- Weakness/sweating

- $\quad$ Fatigue

- Shortness of breath

- Weakness

- Gait instability

- Falls

- Dizziness

- Fainting spells

- Palpitations

- Chest pain

- Depression

- Memory problems

- Black stools

- Bright red blood per rectum

- Diarrhea

- Constipation

- Abdominal pain

- Vomiting/nausea

- Back pain

- Weight loss

\section{Differential diagnosis/work-up}

Elderly patient must also be evaluated for infections, hypoglycemia, dehydration, hypo or hypernatremia, stroke, increased intracranial pressure, myocardial ischemia, tachy or bradyarrythmias or hypotension.

Adverse effects of medications.

In an older patient, cardiac and pulmonary causes must be explored if patient presents with these symptoms: assessment must rule out angina, MI, COPD \&CHF exacerbation.

Symptoms of anemia with lethargy and weakness can mimic depression, hypothyroidism and dementia. Adverse effects of medications.

In post-menopausal women and men $>\mathbf{5 0}$ years of age, presence of these symptoms warrants GI work up: an EGD \& Colonoscopy. Abdominal aortic ultrasound for aortic aneurysm might be indicated.

Adverse effects of medications.

Review patient's: Nutritional habits.

Medications: for use of NSAIDs, anticogulants, high doses of antacids or calcium (TUMS) and steroids.

Past Medical History: Celiac disease, gastric bypass surgery, bleeding disorders, Abdominal aortic aneurysm.

\section{On examination look for:}

- Low Blood Pressure ( also orthostatic hypotension) *

- Tachycardia *

- Thready pulse *

- Respiratory rate *

- Pallor of conjunctiva, lips, mucous membranes and palmer creases

- Koilonychia

- Bruising, ecchymosis, petichiae

- Abdominal tenderness

- Decreased muscle strength

* Alterations in cardiopulmonary responses should be assessed with the patient out of bed and standing or walking.

Fig. (3). Physical and functional assessment of iron deficiency anemia in an older adult. 


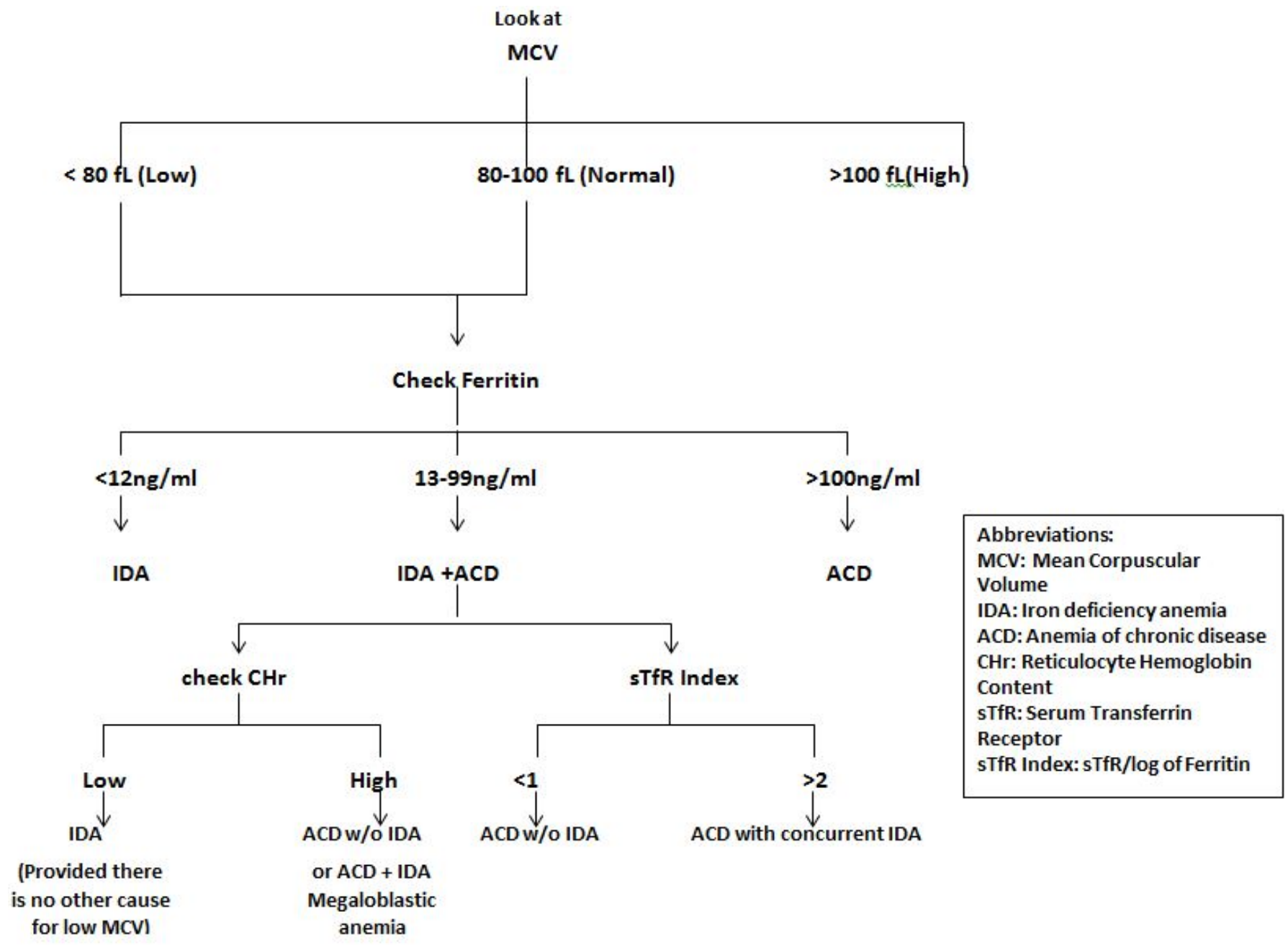

Fig. (4). CBC with hemoglobin $<12 \mathrm{~g} / \mathrm{dL}$ in women and $<13 \mathrm{~g} / \mathrm{dL}$ in men.

Laboratory tests: There are several laboratory investigations for assessing iron status in patients but diagnosing Iron deficiency in the elderly is often a challenge as most of the available tests have limitations. There are many algorithms for the laboratory diagnosis of anemia which can often be very complex. Since our focus is on iron deficiency, we have provided a simple outline for the laboratory evaluation of elderly patients (Fig. 4).

\section{Mature Erythrocyte Indices}

RBC size: This is an important nonspecific marker for nutritional anemias [26]. In the elderly, however, because of multifactorial etiology, it does not always aid in diagnosis. A recent study showed only $27.5 \%$ of patients with IDA to have microcytosis and just $7.4 \%$ of patients with folic acid and/or cyanocobalamin deficiency to have macrocytosis [29]. In pure iron deficiency anemia RBC is microcytic $(\mathrm{MCV}<80)$ whereas when anemia is only due to inadequate folate and/or cobalamin levels, it is macrocytic $(\mathrm{MCV}>120)$ $[27,30]$.

Red blood cell distribution width (RDW): A measure of heterogeneity in red blood cell volume distribution is also considered a sensitive indicator of IDA (sensitivity $81 \%$ and specificity 53.4\%) [31].

\section{Markers of Iron Stores, Uptake and Metabolism}

Serum Ferritin: is considered by many to be the best test available for detecting iron deficiency [31-33]. It reflects iron stores and decreases in iron deficiency anemia. However, ferritin is also an acute phase reactant and its elevation is influenced by inflammation (chronic infections, autoimmune diseases, malignancy, etc.). In certain inflammatory conditions such as RA, CHF and CKD, 'functional iron deficiency' occurs whereby there is ironrestricted erythropoiesis despite adequate iron stores causing Ferritin level to be either normal or elevated. This is a condition frequently termed Anemia of Chronic Disease (ACD) [34]. Functional iron deficiency is thought to be modulated by Hepcidin, a small polypeptide, produced by the liver that acts as a direct mediator of iron homeostasis. It also acts as an acute phase reactant and is elevated in the presence of pro-inflammatory cytokines. Increased levels of hepcidinprevent gastrointestinal absorption of iron, release of iron from the hepatic reserves and from macrophage/ monocytes to erythroidproginator cells $[34,35]$.

However, Ferritin levels $\leq 12 \mu \mathrm{g} / \mathrm{dl}$ are diagnostic of iron deficiency and levels $\geq 100 \mu \mathrm{g} / \mathrm{dl}$ reliably rule out iron deficiency. Levels between 13-99 $\mu \mathrm{g} / \mathrm{dl}$ remain an area of undetermined significance [36]. 
Transferrin Saturation (TSAT): is the percent of iron bound transferrin. It is the ratio of serum iron and total iron binding capacity, multiplied by 100 . The normal level is between $20 \%-50 \%$. Iron deficiency, if not complicated by concomitant inflammatory disease, will yield a low TSAT $(<20 \%)$. TSAT also behaves as an acute-phase reactant as transferrin may be high in inflammatory states. This would result in a lower TSAT if serum Iron stays constant. A TSAT of $20 \%$ has a sensitivity between $81-88 \%$, and iron deficiencyanemia with a TSAT higher than $20 \%$ is uncommon [37, 38].

Serum Transferrin Receptor (sTfR): is a transferrin receptor (TfR) that is localized on the surface of erythroid precursors [39]. It is considered to be a sensitive alternative for assessment of iron stores with normal levels being between $2.6-9.9 \mathrm{mg} / \mathrm{dl}$. sTfR has an inverse relationship with tissue iron stores and increased levels are indicative of iron deficiency [33]. Decreased levels of sTfR are present in hematologic conditions such as erythroid aplasia, erythroidhypoplasia as well as in conditions of severe iron overload. STfR levels are elevated in patients receiving erythropoietin therapy or in those with hemolytic anemias, erythroidhyperplasiasor severe megaloblastic anemia [39].

STfR Index: The ratio of sTfR to $\log$ of serum ferritin (sTfR/log Ferritin) is a highly predictive test for the estimation of iron stores in the body. However, it is not a commonly performed test in clinical laboratories [32]. The sTfR Index is useful in the presence of ACD as suggested by elevated C-reactive protein [39].

Zinc Protoporphyrin/Heme Ratio: identifies depletion of iron stores prior to development of anemia. It is a predictor of iron status in the bone marrow during erythrocyte production. When iron is inadequate, zinc movement across the intestinal membrane is increased to substitute for the missing iron in protoporphyrin ring production. This test has limited specificity as zinc protoporphyrin rises in conditions such as inflammation, ACD and hemoglobinopathies [31].

\section{Reticulocyte Indices}

Reticulocyte Hemoglobin Content (CHr): The $\mathrm{CHr}$ provides an indirect assessment of the availability of functional iron for erythropoiesis over the past three to four days [31, 33]. Thus $\mathrm{CHr}$ has been useful in detecting functional iron deficiency that is present in ACD and hence need for iron supplementation [35]. Low CHr is also seen in the absence of iron deficiency in certain conditions such as hemoglobinopathies (thalassemia) that produce microcytic anemia. Similarly, CHr may be increased in patients with megaloblastic anemia and iron deficiency [35, 40, 41].

\section{Bone Marrow Biopsy}

If the diagnosis of anemia remains unclear after extensive lab testing, a bone marrow biopsy may be performed. The gold standard test for the diagnosis of iron deficiency anemia is the absence of stainable iron in the bone marrow.

\section{Gastrointestinal (GI) Evaluation}

This is extremely important in investigating iron deficiency anemia in older adults, as almost $60 \%$ of IDA patients over the age of fifty have a gastrointestinal source.

Fecal Occult Blood Testing (FOBT): is used commonly to detect blood loss in the stool that is not visible on gross inspection. It is usually less than $50 \mathrm{mg}$ of $\mathrm{Hb}$ per gram of stool. Normal adults usually lose less than 2 to $3 \mathrm{mg} / \mathrm{g}$ of stool [42]. Blood loss of at least 10 milliliters per day is needed to give a positive result on this test. In men over the age of 50 and postmenopausal women, the use of this test is discouraged since irrespective of the FOBT result upper and lower GI endoscopy is strongly recommended if bleeding is suspected [33].

Upper and Lower GI evaluation: is recommended in all postmenopausal women and men over the age of 50 who have a confirmed diagnosis of IDA in the absence of overt non-GI blood loss [9]. There is little consensus on the degree of anemia warranting investigation. In the elderly individuals with iron deficiency, GI evaluation is recommended irrespective of the $\mathrm{Hb}$ level since a similar prevalence of GI lesions was observed in iron depleted patients without anemia as in those with anemia $[31,43]$.

GI evaluation comprises endoscopic testing including EGD, Colonoscopy, enteroscopy and wireless capsule endoscopy (WCE) and radiographic tests: barium enema, upper GI series with or without small bowel follow through, enteroclysis, abdominal Computer Tomograpy (CT) and CT colonography. The choice or appropriateness of test depends on multiple factors which include: type \& location of the lesion, patient's condition (frailty, severe co-morbidities) and availability of test, presence of contraindications to a particular test and potential fitness of the patient to tolerate treatment in the event a colorectal cause is identified. However, Endoscopic modalities are diagnostically superior to radiographic tests as they allow direct visualization of lesions, and often treatment (resection of polyps/adenomas) and performance of biopsies. Nevertheless all tests have their limitations and may not be appropriate in all situations [31].

Those over the age of 50 with marked anemia or with family history of colon cancer should still undergo lower GI investigation even if they have been found to have celiac disease [32]. Approximately, 5-10\% of patients with anemia have no lesions found on endoscopic evaluation with EGD and colonoscopy. According to the American Gastroenterological Association (AGA), patients who have persistent or recurrent IDA after negative EGD or colonoscopy should undergo small bowel evaluation and WCE should be the desired method for examining the small bowel [31].

\section{Non-Transfusion Therapy of Iron Deficiency Anemia}

If the patient is stable and asymptomatic then iron should be replaced orally with dietary supplementation. As a first step, assessment of the patient's diet should be undertaken 
with recommendations to include iron rich foods (i.e. fortified cereals and breads, red meat, beans, green leafy vegetables). It may be beneficial to get a registered dietitian or a licensed nutritionist to assist in the proper education of required dietary changes. Often diet alone is inadequate to correct the anemia and oral iron therapy is required.

Oral Iron Therapy: is the first line therapy for IDA. It is cheap, effective, safe and convenient [31,33]. Ferrous sulfate, ferrous fumerate and ferrous gluconate are the available oral forms and are usually prescribed as twice daily dosing in the elderly. It is, however, important to know that a single tablet of ferrous sulfate contains twice the amount of elemental iron as a tablet of the other two formulations. Also all three formulations are available in enteric coated and non-enteric coated forms. The enteric coated-delayed release preparations may be better tolerated but are less effective as they have less elemental iron [44]. Patients who do not show an adequate response to enteric coated-delayed release formulations may show a good response to non-enteric coated ferrous preparations.

Iron is better absorbed in acidic environment (in the ferrous versus ferric form) and its efficacy can be further optimized by taking it with orange juice or ascorbic acid tabs (250-500 mg twice daily) [31, 32, 44]. Foods (tea, coffee, phosphate containing carbonated beverages like soft drinks) and medications (antacids, proton pump inhibitors and $\mathrm{H}_{2}$ blockers) that inhibit gastric acid secretion must be avoided at the time of iron therapy administration. Oral iron therapy should generally be taken 1-2 hours after taking an antacid. The acid suppressive effect of $\mathrm{H}_{2}$ blockers and proton pump inhibitors is even more extended. Hence, iron tablets should be taken at bedtime when the alkalizing effect of food isminimum and gastric acid production is active.

Often upper (epigastric discomfort and nausea) and/or lower (constipation and diarrhea) GI side effects develop on oral iron therapy. These can be managed by dose reduction (prolonging dosing intervals) or changing the iron formulation [44]. An increase of $2 \mathrm{~g} / \mathrm{dl}$ in the hemoglobin level is considered to be an adequate response to oral supplementation [34]. Oral Iron Therapy should be continued for 2-3 months after anemia resolution in order to restore the body's iron stores [45]. Once IDA resolves, it is recommended to perform a 3 monthly evaluation of $\mathrm{Hb}$ and red cell indices for one year, then after a further year and again if symptoms of anemia develop after that [32].

Intravenous Iron Therapy: Three main indications for parenteral iron therapy are:

i. Failure of oral iron therapy: often patients are not able to tolerate the side effects (constipation, nausea, vomiting and abdominal discomfort) or fail to be complaint with oral therapy.

ii. Iron malabsorption occurs in malabsorption syndromes such as Celiac disease (now increasingly recognized in elderly individuals), conditions of decreased gastric acid secretion as in atrophic gastritis or with $\mathrm{H}_{2}$ blockers and Proton Pump Inhibitors (PPI) or in the event of partial gastrectomy or gastric stapling for obesity.

iii. High iron requirements: in situations of excessive GI bleeding or in chronic hemodialysis, the iron absorbing capacity of the gut is overwhelmed.
Intravenous iron is available in 4 forms: iron dextran; this was the only available formulation in the United States until recently. It can be administered in large doses on a single occasion but the dextran moiety has the potential to cause serious anaphylactic reaction. Iron gluconate and sucrose have recently been approved in the US: these formulations do not carry the serious threat of potentially fatal allergic reaction but can only be administered in limited doses [46]. Ferric carboxylmaltose is a new intravenous iron formulation that can be given safely in high single weekly doses at much higher infusion rates than other parenteral iron formulations [31].

While administering intravenous iron therapy, patient must be watched closely for any signs/symptoms and also evaluated for laboratory evidence of iron overload. Serum ferritin $>800-1000 \mu \mathrm{g} / \mathrm{dl}$, transferrin saturation more than $50 \%$ or abnormal liver function tests are indicators of iron toxicity. Parenteral iron administration must be stopped if these levels are exceeded otherwise there is a high risk of iron deposition in the organ such as the heart, liver and pancreas [46].

\section{CONCLUSION}

Anemia is a significant problem in the elderly and it should not be considered an inevitable consequence of aging. Over the last 10 years multiple studies have outlined the adverse acute and long-term consequences of anemia such as delirium, weakness, immobility, falls, prolonged hospitalization and an increase in mortality. A cause for anemia is usually found in up to $80 \%$ of elderly patients, hence it must be investigated thoroughly and treated appropriately.

Iron deficiency anemia is the predominant form of anemia that occurs in the older population, most commonly as a result of gastrointestinal losses. When it develops acutely, it can become life-threatening if not identified and treated in a timely manner. Patients with anemia must be examined thoroughly for signs of volume depletion and hemodynamic instability. Nonspecific symptoms such as shortness of breath, fatigue, dizziness, confusion and lethargy are often attributed to comorbidities in an older person or simply aging, resulting in a delay in diagnosis or misdiagnosis. Management decisions regarding anemia should involve functional assessment of the elderly subject. Immediate arrangements for transfusion must be made if the elderly patient is symptomatic irrespective of the hemoglobin level. Evaluation and treatment of iron deficiency anemia can also be performed in the out-patient setting, with potential cost savings and reduced morbidity, length of hospital stay, rehabilitation and premature nursing home placement. Our case series as well as a number of clinical trials have demonstrated that appropriate treatment of anemia can result in substantial improvements in functional capacity, productivity and quality of life of the elderly.

\section{CONFLICT OF INTEREST}

The authors confirm that this article content has no conflict of interest.

\section{ACKNOWLEDGEMENTS}

This research was supported by the Claude D. Pepper Older American Independence Center grant (1P30AG28718-01A2). 
We are grateful to Stephen Foster and Kelly Pollnow for their expert assistance with manuscript preparation.

\section{REFERENCES}

[1] Kassebaum NJ, Jasrasaria R, Naghavi M, et al. A systematic analysis of global anemia burden from 1990 to 2010. Blood 2014; 123(5): 61524.

[2] Riva E, Tettamanti M, Mosconi P, et al. Association of mild anemia with hospitalization and mortality in the elderly: the Health and Anemia population-based study. Haematologica 2009; 94(1): 22-8.

[3] Dharmarajan TS, Avula S, Norkus EP. Anemia increases risk for falls in hospitalized older adults: an evaluation of falls in 362 hospitalized, ambulatory, long-term care, and community patients. J Am Med Dir Assoc 2006; 7(5): 287-93.

[4] Patel KV. Epidemiology of anemia in older adults. Semin Hematol 2008; 45(4): 210-7.

[5] Guralnik JM, Eisenstaedt RS, Ferrucci L, Klein HG, Woodman RC. Prevalence of anemia in persons 65 years and older in the United States: evidence for a high rate of unexplained anemia. Blood 2004; 104(8): 2263-8.

[6] Makipour S, Kanapuru B, Ershler WB. Unexplained anemia in the elderly. Semin Hematol 2008; 45(4): 250-4.

[7] Carson JL, Grossman BJ, Kleinman S, Tinmouth AT, Marques MB, Fung MK. Red blood cell transfusion: a clinical practice guideline from the AABB*. Ann Intern Med 2012; 157(1): 49-58.

[8] Culleton BF, Manns BJ, Zhang J, Tonelli M, Klarenbach S, Hemmelgarn BR. Impact of anemia on hospitalization and mortality in older adults. Blood 2006; 107(10): 3841-6.

[9] Denny SD, Kuchibhatla MN, Cohen HJ. Impact of anemia on mortality, cognition, and function in community-dwelling elderly. Am J Med 2006; 119(4): 327-34.

[10] Penninx BW, Pahor M, Woodman RC, Guralnik JM. Anemia in old age is associated with increased mortality and hospitalization. J Gerontol A Biol Sci Med Sci 2006; 61(5): 474-9.

[11] den Elzen WP, Willems JM, Westendorp RG, de Craen AJ, Assendelft WJ, Gussekloo J. Effect of anemia and comorbidity on functional status and mortality in old age: results from the Leiden 85-plus Study. CMAJ 2009; 181(3-4): 151-7.

[12] Inouye SK, Westendorp RG, Saczynski JS. Delirium in elderly people. Lancet 2014; 383(9920): 911-22.

[13] Fick DM, Steis MR, Waller JL, Inouye SK. Delirium superimposed on dementia is associated with prolonged length of stay and poor outcomes in hospitalized older adults. J Hosp Med 2013; 8(9): 500-5.

[14] Fong TG, Tulebaev SR, Inouye SK. Delirium in elderly adults: diagnosis, prevention and treatment. Nature Rev Neurol 2009; 5(4): 210-20.

[15] Burkhart CS, Birkner-Binder D, Steiner LA. [Delirium in the intensive care unit]. Therapeutische Umschau Revue therapeutique 2010; 67(2): $75-8$.

[16] Joosten E, Lemiengre J, Nelis T, Verbeke G, Milisen K. Is anaemia a risk factor for delirium in an acute geriatric population? Gerontology 2006; 52(6): 382-5.

[17] Granberg Axell AI, Malmros CW, Bergbom IL, Lundberg DB. Intensive care unit syndrome/delirium is associated with anemia, drug therapy and duration of ventilation treatment. Acta Anaesthesiol Scand 2002; 46(6): 726-31.

[18] Kazmierski J, Kowman M, Banach M, et al. Incidence and predictors of delirium after cardiac surgery: results from The IPDACS Study. J Psychosom Res 2010; 69(2): 179-85.

[19] Hong CH, Falvey C, Harris TB, et al. Anemia and risk of dementia in older adults: findings from the Health ABC study. Neurology 2013; 81(6): 528-33.

[20] Atti AR, Palmer K, Volpato S, Zuliani G, Winblad B, Fratiglioni L. Anaemia increases the risk of dementia in cognitively intact elderly. Neurobiol Aging 2006; 27(2): 278-84.
[21] Shah RC, Buchman AS, Wilson RS, Leurgans SE, Bennett DA. Hemoglobin level in older persons and incident Alzheimer disease: prospective cohort analysis. Neurology 2011; 77(3): 219-26.

[22] Chaves PH. Functional outcomes of anemia in older adults. Semin Hematol 2008; 45(4): 255-60.

[23] Penninx BW, Pahor M, Cesari M, et al. Anemia is associated with disability and decreased physical performance and muscle strength in the elderly. J Am Geriatr Soc 2004; 52(5): 719-24.

[24] Hazzard WR. Principles of Geriatric Medicine and Gerontology: McGraw-Hill Professional Publishing; 2003.

[25] NHANES-National Health and Nutrition Examination Survey Homepage. 9/24.

[26] Carmel R. Nutritional anemias and the elderly. Semin Hematol 2008; 45(4): 225-34.

[27] Andres E, Serraj K, Federici L, Vogel T, Kaltenbach G. Anemia in elderly patients: new insight into an old disorder. Geriatr Gerontol Int 2013; 13(3): 519-27.

[28] Ballard HS. The hematological complications of alcoholism. Alcohol Health Res World 1997; 21(1): 42-52.

[29] Petrosyan I, Blaison G, Andres E, Federici L. Anaemia in the elderly: an aetiologic profile of a prospective cohort of 95 hospitalised patients. Eur J Int Med 2012; 23(6): 524-8.

[30] Gabrilove J. Anemia and the elderly: clinical considerations. Best Pract Res Clin Haematol 2005; 18(3): 417-22.

[31] Zhu A, Kaneshiro M, Kaunitz JD. Evaluation and treatment of iron deficiency anemia: a gastroenterological perspective. Dig Dis Sci 2010 55(3): 548-59.

[32] Goddard AF, James MW, McIntyre AS, Scott BB. Guidelines for the management of iron deficiency anaemia. Gut 2011; 60(10): 1309-16.

[33] Clark SF. Iron deficiency anemia: diagnosis and management. Curr Opin Gastroenterol 2009; 25(2): 122-8.

[34] Mast AE, Blinder MA, Dietzen DJ. Reticulocyte hemoglobin content. Am J Hematol 2008; 83(4): 307-10.

[35] Wish JB. Assessing iron status: beyond serum ferritin and transferrin saturation. CJASN 2006; 1(Suppl 1): S4-8.

[36] Eisenstaedt R, Penninx BW, Woodman RC. Anemia in the elderly: current understanding and emerging concepts. Blood Rev 2006; 20(4): 213-26.

[37] Fishbane S, Kowalski EA, Imbriano LJ, Maesaka JK. The evaluation of iron status in hemodialysis patients. J Am Soc Nephrol 1996; 7(12): 2654-7.

[38] Kalantar-Zadeh K, Hoffken B, Wunsch H, Fink H, Kleiner M, Luft FC. Diagnosis of iron deficiency anemia in renal failure patients during the post-erythropoietin era. Am J Kidney Dis 1995; 26(2): 292-9.

[39] Skikne BS. Serum transferrin receptor. Am J Hematol 2008; 83(11): 872-5.

[40] Mast AE, Blinder MA, Lu Q, Flax S, Dietzen DJ. Clinical utility of the reticulocyte hemoglobin content in the diagnosis of iron deficiency. Blood 2002; 99(4): 1489-91.

[41] Skarmoutsou C, Papassotiriou I, Traeger-Synodinos J, et al. Erythroid bone marrow activity and red cell hemoglobinization in iron sufficien beta-thalassemia heterozygotes as reflected by soluble transferrin receptor and reticulocyte hemoglobin in content. Correlation with genotypes and $\mathrm{Hb} \mathrm{A}(2)$ levels. Haematologica 2003; 88(6): 631-6.

[42] Walker HK, Hall WD, Hurst JW. Clinical methods: the history, physical, and laboratory examinations: Butterworths 1990.

[43] Joosten E, Ghesquiere B, Linthoudt $\mathrm{H}$, et al. Upper and lower gastrointestinal evaluation of elderly inpatients who are iron deficient Am J Med 1999; 107(1): 24-9.

[44] Alleyne M, Horne MK, Miller JL. Individualized treatment for irondeficiency anemia in adults. Am J Med 2008; 121(11): 943-8.

[45] Umbreit J. Iron deficiency: a concise review. Am J Hematol 2005; 78(3): 225-31.

[46] Macdougall IC. Strategies for iron supplementation: oral versus intravenous. Kidney Int Suppl 1999; 69: S61-6.

This is an open access article licensed under the terms of the Creative Commons Attribution Non-Commercial License (http://creativecommons.org/licenses/by$\mathrm{nc} / 3.0 /$ ) which permits unrestricted, non-commercial use, distribution and reproduction in any medium, provided the work is properly cited. 